\title{
The Generational Differences in Work Values and its Impact on Workplace Conflicts of Operational Level Employees in Pharmaceutical Companies of Western Province, Sri Lanka
}

\author{
G. R. Preena, W. M. S. K. Wanigasekara \\ University of Kelaniya, Sri Lanka \\ preenar@kln.ac.lk, saroja@kln.ac.lk
}

\begin{abstract}
Workplace conflicts among employees in different generations are inevitable due to differences in aging, experience, life stage, expectations, career stage, and the work values they admired. Thus, this study aimed at identifying whether there is a significant impact of generational differences in work values on workplace conflicts. Accordingly, the primary data for the study was collected through a survey by distributing a standard questionnaire among 120 operational level employees who are working in Pharmaceutical companies in the Western Province, Sri Lanka. For the data analysis and arriving at conclusions, descriptive statistics, correlation analysis, and one-way ANOVA used. The analyzed data revealed that there is no significant impact of generational differences in work values on workplace conflicts. However, further analysis done using one-way ANOVA showed that there is a significant difference in work values between generations and workplace conflicts between generations. Hence, the findings of this study will be a better decisionmaking guideline for policymakers and managers in pharmaceutical companies in arriving at various employee-related decisions and improving employee-related work policies in organizations concerning workplace conflicts and grievance handling as well as for the academics and students in the field of social science for research and study purposes.
\end{abstract}

Keywords: Generational differences in work values, Workplace conflicts, Operational level employees, Pharmaceutical companies.

\section{Introduction}

Numerous researchers have revealed that generational differences exist among various generations and is varied with the characteristics associated with employee behavior and work values, leading to influence employee engagement and cohesion (Gursoy, Maierb, \& Chic, 2008; Gursoy, Karadag, \& Chi, 2013; Lancaster \& Stillman, 2002). Thus, conflicts between employees of different generations like Baby Boomers, Generation Xers, and Millennials or Generation Yers, is frequent at work due to difficulties of getting along with each other. Also, studies have indicated that these generational differences may arise due to various aspects of the professional and personal life of the employee as well (Macky, Gardner, Forsyth, \& Cennamo, 2008; Rousseau \& Greller, 1994). The presence of employees belong to various generations in the workplace creates conflicts among employees (Geddie \& Jackson, 2002; Lancaster \& Stillman, 2002; Griffin, 2004). Also, these generational distinctions could build incompatibilities between the relationships of supervisors and subordinates as well (Collins, Hair, \& Rocco, 2009). Further, researchers have identified that employee productivity, communication, and coordination to achieve goals too affected by gaps among different generations other than the organizational performance (Collins, Hair, \& Rocco, 2009).

Even though there are many research studies related to generational differences in work values and workplace conflicts, the majority of such studies have tested the work values of employees in the manufacturing industry (Smola \& Sutton, 2002; Mikitka, 2009). However, in this study, the researchers attempt to assess the impact of generational differences in work values on the workplace conflicts of operational level employees of pharmaceutical companies in the Western province of Sri Lanka. Since the discussions had with few managers of pharmaceutical companies by the researchers revealed that workplace conflicts among generations are prominent due to differences among the work values of employees of each generation when they are getting along with each other. Further, it has identified that workplace conflicts often created over demands for work-life flexibility, followed by rules and attitudes that are evolving as a result of improvements in technology (Levenson \& Deal, 2016). Thus, analyzing the impact of generational differences in work values on workplace conflicts of operational level employees in pharmaceutical companies of Western Province, Sri Lanka serves as the primary objective of the study. In contrast, the secondary objectives are (i) to identify whether there is a significant difference in work values between generations (ii) to identify whether there is a significant difference in workplace conflicts between 
generations.

\section{Literature Review}

In the modern business environment, employees from different generations are working together (Gursoy, Maierb, \& Chic, 2008). Here, a generation could be defined as a collection of people with similar ages or born on a given period that shares significant life events and possess identical personality types and feelings towards works and personal life in satisfying their means (Kupperschmidt, 2018). In other words, a generation is a collection of people born and raised in a similar social context (Mannheim, 1953). Accordingly, the employees of the current workforce belong to three generations namely, Baby Boomers (employees who born between 1946 to 1964), Generation X (employees who born between1965 to 1983), and Millennial Generation (employees who born between1984 to 2002) (Levenson \& Deal, 2016). The workplace conflicts among these generations are frequent at work due to differences in aging, life stage, experience, expectations, career stage, and the work values they hold and value. Accordingly, employees from different generations find it difficult in working closely together due to the above differences leading to workplace conflicts.

Further, it has identified that workplace conflicts often created over demands for work-life flexibility, followed by rules and attitudes that are evolving as a result of improvements in technology (Levenson \& Deal, 2016). Also, many researchers have generally conceptualized interpersonal conflict as a concept with two dimensions, namely cognitive and relational conflicts (Rahim, 1983; Pinkley, 1990; Priem \& Price, 1991; Jehn, 1995; Simons \& Peterson, 2000). Cognitive conflicts often arise due to inconsistencies in performing various tasks (Jehn, 1995; Putnam \& Wilson, 1982; Roloff, 1987), whereas relational conflicts caused by emotional incompatibilities (Thomas, 1992; Jehn \& Mannix, 2001; Rahim, 2002) and interfering or disruptive behavior (Alper, Tjosvold, \& Law, 2000). Accordingly, in this study, the researchers defined workplace conflicts as a combination of both cognitive and relational conflicts.

Also, Lancaster and Stillman (2002) have stated that if generational differences effectively managed, it could use as a tool to nurture the business. Also, understanding and respecting these generational differences and associated work values could empower companies to perform (Egri \& Ralston, 2004; Kupperschmidt, 2000). When it comes to values, values are the indicators that represent actions and decisions of individuals (Rokeach, 1973); also, these values are static and do not change frequently (Ravlin \& Meglino, 1987; Ravlin \& Meglino, 1989; Rokeach, 1973). Thus, understanding these work values is essential since the extent to which employees adhere to these work values influence their attitude towards the job. Accordingly, in this study, the generational differences in work values considered as the independent variable, where it has divided further into five dimensions, as mentioned below (Gursoy, Maierb, \& Chic, 2008).

Leisure Rewards: Access to free time, vacation, and autonomy at the workplace.

Intrinsic Rewards: Intangible Rewards. e.g., access to learning and development, opportunities to use creativity.

Altruistic Rewards: The opportunity to contribute to the wellbeing of society and volunteering at helping others.

Social Rewards: Ability to maintain an effective person to person (interpersonal) relationships at work.

Extrinsic Rewards: Tangible rewards given to individuals. e.g., career advancement opportunities, and job status.

Also, workplace conflicts are prominent among operational level employees due to their knowledge gaps and diversity. So this study is based on operational level employees working in the Western province of Sri Lanka; hence employees in this province have been experiencing workplace conflicts. Accordingly, the current research study attempted to identify the impact of generational differences in work values on workplace conflicts. Hence, the researchers have developed the below hypothesis with the aid of the literature.

H1: There is a significant impact of generational differences in work values on workplace conflicts. 
Figure 1: Conceptual Framework

\begin{tabular}{|c|c|}
\hline $\begin{array}{c}\text { Generational Differences in Work } \\
\text { Values }\end{array}$ & $\mathrm{H}_{1}$ \\
\hline
\end{tabular}

Source: Author

\section{Methodology}

Sampling Method: The convenient sampling method is the sampling technique used by the researchers for this study due to the ease of access for the population. The sample comprised 120 operational level employees representing four major pharmaceutical companies in the Western Province of Sri Lanka between the ages of $18-60$, as recommended by Nulty (2008).

Method of Data Collection: The researchers used a standard questionnaire consists of 24 close-ended questions with two parts (generational differences in work values and workplace conflicts) for this study. To assess the generational differences in work values, a questionnaire comprised of five dimensions that were initially developed by Johnson (2000) used. Accordingly, the first dimension leisure rewards measured through four items, and the Cronbach Alpha for this was 0.800. The second dimension intrinsic rewards comprised of seven items scale and the Cronbach Alpha for that was 0.864, while the third dimension, altruistic rewards measured by two items, and its Cronbach Alpha, was 0.774. The social rewards dimension was measured using two items scale, and its Cronbach Alpha accounts for 0.779, whereas the last dimension extrinsic rewards comprised four items with a Cronbach Alpha of 0.865. Accordingly, the tests of reliability were valid to measure the given variable of generational differences in work values. To measure the dependent variable of workplace conflicts, the researchers used the standard questionnaire developed by Doucet, Poitras, and Che (2009), and the workplace conflicts construct measured through five items scale where the Cronbach Alpha was 0.872 .

Data Analysis: The quantitative method was used to analyze the data gathered through a standard questionnaire. Also, a five-point Likert scale that ranges from strongly agree to strongly disagree (5 to 1) used to get the responses from respondents.

\section{Findings}

The sample of this study comprised of $6 \%$ baby boomers, $38 \%$ generation $\mathrm{X}$, and $56 \%$ millennial/ generation Y. Consequently, more millennials have participated in the survey. The mean value of the dependent variable, workplace conflicts, was 3.7864 , which depicted that generational differences in work values prevail within the workplace. Also, the standard deviation was 0.50856 , which lies in between the accepted range.

Table 1: Descriptive of the Dependent Variable

\begin{tabular}{|c|c|c|c|c|c|}
\hline \multicolumn{4}{|c|}{ Descriptive of the Dependent Variable } & \multirow{2}{*}{$\begin{array}{l}\text { Statistic } \\
3.7864\end{array}$} & \multirow{2}{*}{$\begin{array}{l}\text { Std. Error } \\
.04642\end{array}$} \\
\hline \multirow{13}{*}{$\begin{array}{l}\text { Generational } \\
\text { Work Values }\end{array}$} & \multirow{13}{*}{ Differences } & Mean & & & \\
\hline & & 95\% Confidence Interva & forLower Bound & 3.6945 & \\
\hline & & Mean & Upper Bound & 3.8783 & \\
\hline & & 5\% Trimmed Mean & & 3.7953 & \\
\hline & & Median & & 3.7368 & \\
\hline & & Variance & & .259 & \\
\hline & & ${ }^{1 n}$ Std. Deviation & & .50856 & \\
\hline & & Minimum & & 2.53 & \\
\hline & & Maximum & & 5.00 & \\
\hline & & Range & & 2.47 & \\
\hline & & Interquartile Range & & .63 & \\
\hline & & Skewness & & -.200 & .221 \\
\hline & & Kurtosis & & -.059 & .438 \\
\hline
\end{tabular}

Source: Primary Data 
Further, the mean values of generational differences in work values between generations based on born years showed that the baby boomers emphasized much importance on work values than the generation $\mathrm{X}$ and $\mathrm{Y}$, as indicated in the below table.

Table 2: The Mean Values of Generational Differences in Work Values between Generations based on Born Years

\begin{tabular}{lll}
\hline & & $\begin{array}{l}\text { Generational Differences in Work Values } \\
\text { Mean }\end{array}$ \\
\hline \multirow{3}{*}{ Born Year } & Born between 1946-1964 & 3.99 \\
& Born between 1965 - 1983 & 3.65 \\
& Born between 1984 - 2002 & 3.86 \\
\hline
\end{tabular}

Source: Primary Data

The Spearman correlation coefficient was 0.111 , indicated a weak positive relationship between generational differences in work values and workplace conflicts. Further, the correlation coefficient was insignificant at 0.227 . Even though this study initially aimed at finding the impact through regression analysis, it was decided to stop the analysis at correlation due to a weak positive relationship between generational differences in work values and workplace conflicts. Accordingly, the $\mathrm{H} 1$ was rejected. However, further analysis of one-way ANOVA by going one step further showed a significant value of 0.047 for generational differences in work values by born year (generations), concluding that there is a significant difference in work values between generations.

Table 3: One-Way ANOVA for Generational Differences in Work Values by Born Year (Generations)

\begin{tabular}{|c|c|c|c|c|c|}
\hline $\begin{array}{l}\text { ANOVA } \\
\text { Generational } \\
\text { Differences } \\
\text { Work Values }\end{array}$ & Sum of Squares & DF & Mean Square & $\mathbf{F}$ & Sig. \\
\hline Between Groups & 1.571 & 2 & .785 & 3.146 & .047 \\
\hline Within Groups & 29.207 & 117 & .250 & & \\
\hline Total & 30.777 & 119 & & & \\
\hline
\end{tabular}

Source: Primary Data

As indicated in Table 4, the significant value of one-way ANOVA for workplace conflicts by the born year was 0.001 , where it revealed that there is a significant difference in workplace conflicts between generations.

Table 4: One-Way ANOVA for Workplace Conflicts by Born Year (Generations)

\begin{tabular}{llllll}
\hline $\begin{array}{l}\text { ANOVA } \\
\text { Workplace Conflicts }\end{array}$ & Sum of Squares & DF & Mean Square & F & Sig. \\
\hline Between Groups & 8.904 & 2 & 4.452 & 7.801 & .001 \\
Within Groups & 66.771 & 117 & .571 & & \\
Total & 75.675 & 119 & & & \\
\hline
\end{tabular}

Source: Primary Data

\section{Conclusion}

The current study focused on testing the impact of generational differences in work values on workplace conflicts of operational level employees in the pharmaceutical companies of the Western province, Sri Lanka. Accordingly, analyzing the impact of generational differences in work values on workplace conflicts was the primary objective of the study. In contrast, specific objectives were to identify whether there is a significant difference in work values between generations and to identify whether there is a significant difference in workplace conflicts between generations. The findings of data analysis revealed that there is no significant impact of generational differences in work values on workplace conflicts. However, further analysis done using one-way ANOVA provided evidence that there are significant differences in work values between generations as well as workplace conflicts between generations. Thus, these findings indicated that it needs to 
create an atmosphere with opportunities within the organizations where each generation could accommodate and interact with each other, which will lead to increase employee motivation and cohesion. Accordingly, the final findings of this research study achieved the established specific objectives successfully, even though it could not reach the established primary objective.

Recommendations: Redesign jobs and reward packages (both intrinsic and extrinsic) based on the work values admired by each generation will assist organizations to retain their employees and create a conducive working environment. Also, considering the differences of work values among various generations in formulating policies and in making decisions would assist in creating positive supervisor and subordinate relationship as well as positive peer to peer relationship within the organization. Further, managers in the work setting should better understand the changes in the work values associated with each generation to reduce undue tension among employees and to promote job satisfaction and productivity. For example, companies could allow millennials to work in flex time as they value much autonomy. In addition to that, developing flexible employee-related policies linked with work practices will help the organization to attract and retain talented employees from different generations. Accordingly, by implementing the above suggestions in the workplace would assist in creating an effective and efficient working environment with the collaboration of employees in all generations by using their differences in work values in a more strategic manner.

\section{References}

Alper, S., Tjosvold, D. \& Law, K. S. (2000). Conflict management, efficacy, and performance in organizational teams. Personnel psychology, 625-642.

Collins, M. H., Hair, J. J. \& Rocco, T. S. (2009). The older-worker-younger-supervisor dyad: A test of the Reverse Pygmalion effect. Human resource development quarterly, 21-41.

Doucet, O., Poitras, J. \& Che, N. D. (2009). The impact of leadership on workplace conflicts. International Journal of Conflict Management, 340-354.

Egri, C. P. \& Ralston, D. A. (2004). Generation cohorts and personal values: A comparison of China and the United States. Organization Science, 210-220.

Geddie, M. W. \& Jackson, F. H. (2002). Age Diversity in Hospitality-Making a Case for the Mature Employee. Journal of Human Resources in Hospitality \& Tourism, 71-83.

Griffin, L. J. (2004). Generations and collective memory revisited. Race, region, and memory of civil rights. American sociological review, 544-557.

Gursoy, D., Maierb, T. A. \& Chic, C. G. (2008). Generational differences: An examination of work values and generational gaps in the hospitality workforce.

Gursoy, Karadag. \& Chi, G. Q. (2013). Generational differences in work values and attitudes among frontline and service contact employees. International Journal of Hospitality Management, 40-48.

Jehn, K. A. (1995). A multimethod examination of the benefits and detriments of intragroup conflict. Administrative science quarterly, 256-282.

Jehn, K. A. \& Mannix, E. A. (2001). The dynamic nature of conflict: A longitudinal study of intragroup conflict and group performance. Academy of management journal, 238-251.

Johnson, M. K. (2000). Change in job values during the transition to adulthood. Work and Occupations, 315345.

Kupperschmidt, B. R. (2000). Multi-generational employees: strategies for effective management, The Health Care Manager, 65-76.

Kupperschmidt, B. R. (2018). Multi-generational Employees: Strategies for Effective Management. International Journal of Economics \& Management Sciences.

Lancaster, L. C. \& Stillman, D. (2002). When generations collide: Who they are. Why they.

Levenson, A. \& Deal, J. J. (2016). What Millennials Want From Work. California: McGraw-Hill.

Macky, L., Gardner, D., Forsyth, S. \& Cennamo, L. (2008). Generational differences in work values, outcomes and person-organization values fit. Journal of managerial psychology.

Mannheim, K. (1953). American sociology. Essays on sociology and social psychology, 185-194.

Mikitka, M. (2009). Managing the multi-generational workforce. Material Handling Management.

Nulty, D. D. (2008). The adequacy of response rates to online and paper surveys: what can be done? Assessment \& evaluation in higher education, 301-314. 
Pinkley, R. L. (1990). Dimensions of conflict frame: Disputant interpretations of conflict. Journal of applied psychology, 117.

Priem, R. L. \& Price, K. H. (1991). Process and outcome expectations for the dialectical inquiry, devil's advocacy, and consensus techniques of strategic decision making. Group \& Organization Studies, 206225.

Putnam, L. L. \& Wilson, C. E. (1982). Communicative strategies in organizational conflicts: Reliability and validity of a measurement scale. Annals of the International Communication Association, 629- 652.

Rahim, M. A. (1983). Organizational conflict inventory. Consulting Psychologists Press.

Rahim, M. A. (2002). Toward a theory of managing organizational conflict. International journal of conflict management.

Ravlin, E. C. \& Meglino, B. M. (1987). Effect of values on perception and decision making: A study of alternative work values measures. Journal of Applied psychology, 666.

Ravlin, E. C. \& Meglino, B. M. (1989). The transitivity of work values: Hierarchical preference ordering of socially desirable stimuli. Organizational behavior and human decision processes, 494-508.

Rokeach, M. (1973). The nature of human values. New York: Free Press.

Roloff, M. E. (1987). Communication and conflict.

Rousseau, D. M. \& Greller, M. M. (1994). Guest editors' overview: Psychological contracts and human resource practices. Human Resource Management (1986-1998), 383.

Simons, T. L. \& Peterson, R. S. (2000). Task conflict and relationship conflict in top management teams: the pivotal role of intragroup trust. Journal of applied psychology, 102.

Smola, W. K. \& Sutton, C. D. (2002). Generational differences: Revisiting generational work values for the new millennium. Journal of Organizational Behavior: The International Journal of Industrial, Occupational and Organizational Psychology and Behavior, 363-382.

Thomas, K. W. (1992). Conflict and conflict management: Reflections and update. Journal of organizational behavior, 265-274. 